\title{
Debatt
}

\section{Den problematiska socialarbetarrollen i ett diskursivt perspektiv}

Med en grasserande psykisk ohälsa bland barn och unga som bakgrund tycks behovet av en ämnesfördjupad socialarbetarkår aldrig ha varit större. I avgörande delar vill jag med nedanstående utspel understryka vikten av samhällsvetenskapliga ansatser i förhållande till den psykiska ohälsans orsakssamband. I så måtto finns det nära nog ingen viktigare arbetsuppgift inom det samhällsvetenskapliga hägnet. Den vägledande vetenskapen finns, men finns där några vetenskapens praktiker?

\section{Sociokultur eller sociomateria?}

Ett västerländskt samhälle som Sverige genomgår snabba förändringar. Normer och värderingar syns vara bundna till ett decennium i taget. Avgjort många förändringar uppstår i relation till kapitalintensiva sektorer. Förändringstakten inom den konsumtionsladdade elektroniksektorn är förmodligen den mest uppdrivna. De uppväxande generationerna är mer känsliga eller receptiva för sentida fenomen varför dessa tämligen omgående integreras som nödvändiga förutsättningar i deras utveckling och livsföring. ${ }^{1}$ Unga människors benägenhet att söka sig till det mya har åtminstone sedan efterkrigstiden blivit ett återkommande föremål för bland annat samhällsvetenskapliga studier eller etablissemangets kritik och ogillande. Benämningar som sedligt försummade, anti-social och vanartighet ${ }^{2}$ har återkommit i beskrivningar av nya normutmanande ungdomsgrupper och ungdomskulturer.

\footnotetext{
1 Unga människor som sitter uppe på nätterna vid datorn, mobiltelefonen eller Tv:n gör det för att elektroniken har öppet dygnet runt. Det tekniska utbudet är omgivningsfaktorer som kan vara både orsak och pålagring till bristande dygnsrytm, sänkt vakenhetsgrad, ökad stresskänslighet eller andra reaktiva påföljder som påverkar social anpassning och följsamhet. För trettio år sedan hade förmodligen motsvarande grupp av unga gått och lagt sig igen (eller inte ens brytt sig att vara uppe) för att det inte fanns något att göra om natten.

2 Omvärldens tillskrivningar och tillika utdefinitioner av mot- och subkulturer, se bl. a Kyhle Westermark, P. (2009) MTFC - en intervention för ungdomar med beteendeproblem. Socialhögskolan, Lunds universitet (Avhandlingsserier:37). Se även en historisk exposé om tillskrivande och diagnoser av Engwall, K. \& Larsson, S. (red) (2012) Utanförskapets historia- om funktionsnedsättning och funktionshinder. Studentlitteratur AB. Lund.
} 


\section{Socialvetenskaplig tidskrift 2015:2}

Gemensamt för den tidigare kritiken var utgångspunkter på gruppnivå ${ }^{3}$ med kopplingar till strukturella tendenser och aktuella normer och värderingar. Inte sällan gjordes kopplingar till familjesociala förhållanden. Idag har benämningarna medicinsk riktning med neurobiologiska implikationer. ${ }^{4}$

Människors olika förutsättningar i en prestationsbaserad och konsumtionsinriktad kultur, som präglas av snabba förändringar, borde vara ett prioriterat akademiskt och praktiskt studium för en yrkeskår som har ambitionen att benämna sig själva som samhälls- och socialarbetare. ${ }^{5}$ För det första bör en sådan yrkeskårs handlingsutrymme säkerställa kunskapsmässiga förutsättningar och samhällelig integritet, inte minst för att stå trygga i de teoretiska skolor som antagit den svåra utmaningen ${ }^{6}$ att förklara samhällsekologins beskaffenheter. En primär uppgift för socialarbetarkåren ligger i att producera kunskap om hur ekologins yttringar återverkar på människan i psykologisk och social bemärkelse. Mitt utrop ter sig måhända förvånande, då Sverige varit och upplevs fortfarande vara ett föregångsland inom ämnet. ${ }^{7}$ Men just den kåren har enligt min uppfattning försvagats eller försvunnit. Det är fullt möjligt, för att använda ett slitet begrepp, att tala om ett paradigmskifte inom svensk välfärdsproduktion. En möjlig delförklaring till paradigmskiftet är effekten av de senaste decenniernas upphöjning och politisering av individstadiet som existentiell slutstation, det vill säga förklaringsmodeller om människors villkor på grupp- eller samhällsnivå harmonierar inte med nutidens vetenskapliga, politiska eller vardagliga trender. Dessa tendenser har möjliggjort att det neurobiologiska företrädet i förståelsen av ungas avvikande beteendemönster har expanderat utan tillbörliga motkontroller. ${ }^{8}$ Paradigmskiftet vilar på hur det svenska samhället, och därmed också den samtida kunskapsproduktionen, genomgått förändringar som successivt har flyttat fokus från samhällsfaktorer till medborgarnas bio-genetiska egenskaper. Det borde betyda att även den yngre kohorten av socialarbetarkåren, och andra yrkesutövande, själva är produkter av det sentida samhällets objektiva framträdelseform. ${ }^{9}$ Även de avspeglar den sociokulturella eran som översprids till yrkesmässiga aktiviteter.

3 Teddyboys, mods, raggare, rockers, hippies, punkare m.m. är benämningar på några ungdomsgrupper som i vissa avseenden har betraktats av övrigt samhälle som motkulturer.

4 Socialstyrelsen medger i sin stora kunskapsöversikt ADHD hos barn och vuxna (2002) att de inte studerat sambanden $\mathrm{ADHD}$ och anknytningsmönster. Inom $\mathrm{f}$. a psykologin och psykoterapin utgör anknytningsstil markör för familjesociala villkor.

5 I texten är socialarbetare, socionom, kurator, kår, social sektor, den sociala kompetensen, socialvetenskap synonymer för ett gemensamt praktiskt kunskapsfält, i relation till samhällsvetenskapliga kunskapsobjekt.

6 I boken Diagnosens makt - Om kunskap, pengar och lidande (2006) pekar sociologiprofessor Thomas Brante på några icke-vetenskapsanknutna orsaker till varför ADHD-diagnosen fått ett så stort genomslag. Brante framför, vilket rimmar väl med rådande tidsanda om effektivitet, att de biologiska förklaringarnas popularitet vinner mark då de utlovar enkla lösningar på komplexa problem.

7 En välkommen och ambitiös motvikt till rådande kunskapssituation har bl.a. varit tidsskriften Psykisk hälsa/Mind och föreningens framtagande av s.k. Mind-index (se Psykisk hälsa 2013:3/Årgång 54/).

8 Samhällsvetenskaplig forskning på exempelvis ADHD förefaller inte vara prioriterat för anslagsgivande institutioner.

9 Även yrkesmänniskor är sociokulturella produkter som avspeglar tidens anda i termer av snabba förändringar, livsåskådning, moral- och rättsuppfattning, professionella ambitioner och arbetsmetoder m.m. 


\section{Idealisering av individens ställning}

Ett ideologiskt och tillika individualistiskt perspektiv på människa och samhälle, som andas var och en är sin egen lyckas smed, för med sig flera underförstådda konsekvenser. En sådan konsekvens kan vara synen på enskilda som ägare av sina livsvillkor varför de också är skickade att förändra dessa. Ansatsen följer förmodligen på föreställningen om att det svenska samhället som helhet är jämlikt och att vi rationellt tävlar om samhällets utbud utifrån något så när lika förutsättningar. I ljuset av att alla medborgare inte besitter sådan självförverkligande tävlingskraft har patologin med stor sannolikhet vunnit insteg. För om samhället antas vara nyttigt för alla så måste orsaker till människors olycka sökas någon annanstans. Just uppfattningen om det allgoda svenska samhället ${ }^{10}$ försvårar eller förhindrar ansatser om multibristsamhället ${ }^{11}$ som underliggande orsak till multiproblem på grupp- och individnivå. Av den anledningen är också fattigdom ${ }^{12}$ i ett rikt samhälle förmodligen mer stigmatiserande och psykologiskt utarmande än att vara fattig bland fattiga. Stigmatiseringen blir i så måtto särskilt kännbar om fattigdomens yttringar och symtom avviker från en förväntad normalitet, som inte i tillräcklig utsträckning underkastas vetenskaplig genomlysning och prövning. Som i alla andra fall kan forskning och vetenskap skänka legitimitet $^{13}$ till ett fenomen, vilket om möjligt är särskilt betydelsefullt när det handlar om något så motsägelsefullt som social utsatthet och psykisk ohälsa i ett välfärdssamhälle. En vetenskaplig legitimitet bidrar också till en förändrad syn som kan fortplantas till andra aktörer och sektorer. Inte minst till media och den så kallade vardagskunskapen. Dessvärre förefaller fattigdomstanken inte längre vara rumsren, medialt gångbar eller ekonomiskt intressant, varför en ensidig eller svag forskningspraktik möjliggör transformering av samhälleliga brister till individuella egenskaper, alltmedan den sociala och psykiatriska kompetensen står handfallna inför den psykiska ohälsans framfart. I detta läge är det förtvivlat anmärkningsvärt att ämnesspecialister inte söker eller når intellektuell konsensus om behovet av ett mer proaktivt angreppssätt på basis av nya eller andra epidemiologiska redskap. ${ }^{14}$ Istället förefaller de inblandade verksamhetsfälten socialt arbete och psykiatri sitta i samma båt där den ena parten till stor del förlitar sig på socialrättsliga kunskaper, den andra på diagnostiska kriterier. Men varken socialrätt eller diagnoser kan prognosticera ohälsa eller förutse framtida vårdbehov, varför huvudsakliga arbetsredskap och betonade uppgifter antar formen av

10 I Sverige vill vi gärna beskrivas utifrån demokratisk parlamentarism, barnomsorg/skola för alla, fri sjukvård, rätten till bistånd enligt socialtjänstlagen etc.

11 Utsatthet som dels sträcker sig över generationer, dels påverkat av multimekanismer som arbetslöshet, barn- och ungdomsvård, omsorgssvikt, missbruk, kriminalitet, ekonomisk utsatthet, bristande skolresultat, bostadssociala svårigheter, andra kontakter med myndighetsutövande instanser m.m.

12 Fattig beskriver socioekonomisk och/eller sociokulturell utsatthet.

13 För drabbade är det i huvudsak en fråga om trovärdighet om att ingen väljer sin egen olycka.

14 Sverige fattas intellektuella praktiker likt Gunnar Inghe. 
administration och service. ${ }^{15}$ Det blir ännu mer svårsmält eftersom det finns hyllmeter efter hyllmeter av vetenskapliga studier som redovisar kända utslagningsmekanismer och psykosociala riskområden, som i sin tur kan kopplas till begreppet multibristsamhälle. Men dessa risker har successivt reducerats till attribut ${ }^{16}$ för andra former av problembeskrivningar, varför multibristsamhället med innebörden ackumulerade och överlappande psykosociala risker mycket sällan framskjuts som ohälsans grundproblem.

\section{Professionell diaspora och otydlig professionsprofil?}

Den tidigare yrkesidentiteten samhällsarbetare håller på att transformeras till en legitimerad socionom utifrån de sjukvårdande huvudmännens preferenser. En sådan förvandling andas andra uppdrag men även annan status. Framförallt stipulerar den andra arbetsuppgifter och kunskapsobjekt. Det är en yrkesroll som lämnar en samhällskritisk och socialvetenskaplig hållning till förmån för biologisk konsensus. Från särskild yrkeskunnighet till understöd. Från resursinventering till problemfokusering. ${ }^{17}$ Gruppen socialarbetare (kuratorer) inom den barn- och ungdomspsykiatriska sektorn förefaller vara den yrkesgrupp som drivit längst bort från det sociala arbetets hörnpelare. ${ }^{18}$ Att framskjuta den sociala kompetensen för att legitimera biologiska slutsatser inom exempelvis barn- och ungdomspsykiatri, har en synnerligen intressant dramaturgi. Sociala perspektiv på uppkomsten av bland annat $\mathrm{ADHD}$ är enligt min mening mer eller mindre tabu inom sjukvården, så vad har kuratorn för roll? Har kuratorn någon legitim möjlighet att framhäva alternativa hypoteser? Har en socionomutbildad kurator tillräckligt med vetenskapliga redskap för att kunna erbjuda intellektuell vidd i frågan? Förmodligen finns likhetstecken mellan kuratorns överlevnad inom sjukvårdssektorn och hur väl den yrkesgruppen övertar sjukvårdens perspektiv. I så måtto förefaller kuratorerna att begå fanflykt som inte kan förklaras bättre än med att de är svaga i sin teoretiska skolning och saknar ämnesdjup som kunde

15 Vårdsektorn vet mycket om målgruppernas problem vid serviceintervallerna, men vad är känt om deras övriga livsvillkor? Organisationernas service-approach inriktar sig mot symtomlindring vid fullbordade faktum. Se Köhler, L (2013), Indikatorer och psykisk ohälsa hos barn - ett folkhälsoperspektiv. Tidskriften Psykisk Hälsa 2013:3/årgång 54/ (organ för föreningen Mind). Edita, Västra Aros.

16 En övervägande del av sjukvårdspsykiatrin betraktar ADHD som ett neuropsykiatriskt tillstånd som om möjligt kan förvärras av omgivningsfaktorer.

17 Inom kommuner och socialtjänst har evidensbaserad praktik blivit unisont med vetenskaplig hållning. Till avgörande delar handlar det om praktiska metoder som riktar sig till individnivå efter aktualisering inom samhällsvården.

18 Ett av flera etiska dilemman för professionen kan vara kollisionen mellan det sociala arbetets emancipatoriska fundament med kategoriseringskritik och sjukvårdens kategoriserande kultur. 
ha medgivit kritiskt tänkande och nyorienterande förståelse om ohälsans orsakssamband. ${ }^{19}$ Sammantaget blir det särskilt nedslående när man beaktar den sociala forskningens relativt långa och framgångsrika historia, där Chicago-skolans ${ }^{20}$ banbrytande arbeten på 1920- och 1930-talen utgör startskottet för modern socialvetenskaplig teorikonstruktion och forskningspraktik.

Därtill knyts epitetet socialarbetare till socionomutbildade kuratorer och i förlängningen auktoriserade eller legitimerade sådana. Av den anledningen är det särskilt bekymmersamt om bristfälligt skolade ${ }^{21}$ och organisatoriskt bakbundna socionomer kan komma att bestämma nivån för vad professionellt socialt arbete är. Och hur ställer sig en auktorisering eller legitimation till andra yrkesgrupper som socialsekreterare, personal på behandlingshem, gruppbostäder, boendestödjare, chefer, familjepedagoger och en mängd andra professioner som arbetar i samhällelig kontext med socialvetenskapligt underbyggda insatser? Hur kan sådana yrken auktoriseras eller legitimeras för att uppnå särskilt bevis på yrkesskicklighet och ska även dessa yrken underkastas sjukvårdens preferenser? Det framstår därför som ett monumentalt tankefel att en yrkesgrupp inom sjukvården ska definiera vad som bör legitimeras inom socialt arbete, även om en legitimation endast är giltig för sjukvårdskurativt arbete. Här pågår en professionens söndring inifrån som mycket olyckligt får sin kraft från professionens centrala och fackliga organ..$^{22}$ Tidskriften Socionomen ${ }^{23}$ menar, med hänvisning till SSR/akademikerförbundets uppfattning, att en legitimation skulle stärka professionella strukturer inom hälso- och sjukvården, vilket samtidigt är en deklaration som inte identifierar ett motsvarande behov inom det samhällsvetenskapliga hägnet och de professioner som verkar därinom. Studier ${ }^{24}$ visar att de svenska sjukvårdskuratorernas svaga professionsprofil kan hänga samman med den svenska yrkesorganisationens dåliga involvering i utvecklingen av en kollektiv professionell identitet. En sådan slutsats är prekär; att socialarbetarkåren som helhet i och med detta får en mycket svag professionsprofil och uppvisar

19 Brante, Thomas (2003) Konsolidering av nya vetenskapliga fält-exemplet forskning $i$ socialt arbete. I Socialt arbete. En nationell genomlysning av ämnet. FAS och högskoleverket 2003:16R, Stockholm. En i texten intervjuad professor i socialt arbete framför bl. a om socialarbetarkårens teoretiska och socialpolitiska medvetenhet: "-Praktiken är idag befolkad av folk...som inte (är) särskilt reflekterande... Man måste kunna förhålla sig till politiska ideologier som svänger fram och tillbaka, kunna ha någon sorts akademisk hållning till detta. Socialtjänsten är som en buffelhjord som går och betar och så - grönt gräs där borta - whoom! - och det finns inte mycket att göra när 3000 ton buffel kommer. ...vi som forskare har en väldigt viktig roll".

20 Humanekologiskt inriktad sociologi som inkluderade såväl urbansociologiska som psykoanalytiska konstruktioner. Förgrundsfigurer inom inriktningen var Georg Mead, Charles H Cooley och Robert E Park.

21 Socionomutbildningen har vid flera tillfällen kritiserats för allvarliga brister. Flera lärosätens examensrätt har ifrågasatts av universitetskanslersämbetet.

22 SSR/akademikerförbundet har enligt egen utsago stridit för legitimation i 50 år, vilket är anmärkningsvärt då socionomutbildningen akademiserades för 37 år sedan (1977).

23 Ledare, nätupplaga, 20130327. http://www.socionomen.nu/text/sjukhuskuratorn-fortfarande-en-social-expert

24 Sjöström, Manuela (2013) To blend in or stand out? Hospital social workers jurisdictional work in Sweden and Germany. Doktorsavhandling. Göteborgs universitet. 
vetenskaplig förflackning är besvärande men följdriktigt ${ }^{25}$ och kan knappast vara gynnsamt för socialarbetarkårens identitet och vetenskapliga hemvist, oavsett hur bra de eftertraktade professionella strukturerna är. En intressant utvikning i sammanhanget gäller den auktorisation för utredningssociologer som fanns när disciplinen socialt arbete etablerade sig som samhällsvetenskapligt ämne i slutet av 1970-talet. Sociologförbundet kom fram till att denna auktorisation skulle skrotas. Uppenbarligen ansåg sociologin att en auktorisation knappast kunde redogöra för vetenskapliga meriter eller förtjänster.

\section{Yrkesrollens utformning}

Socialt arbete som praktik har de senaste decennierna kalibrerats för att möta människor när kris och olycka är ett faktum, vilket i allt väsentligt har kommit att likna sjukvårdens akutverksamheter. ${ }^{26}$ Det torde betyda att en mindre del av välfärdssektorns medel används för reella primärpreventiva insatser, ${ }^{27}$ om man med prevention menar riktade insatser mot samhälleliga företeelser och områden som hypotetiskt kan komma att medföra sociala och psykologiska risker för människor. Storskaliga eller riktade preventionsprogram är naturligtvis inte möjligt om vi inte fortsättningsvis erkänner eller känner till att det svenska samhället är ekonomiskt och kulturellt stratifierat, där nivåskillnaderna medför skarpa innehållsliga och kontextuella olikheter i människors livsföring. Våra olikheter grundläggs tidigt genom socialisation och socialisationens förutsättningar. ${ }^{28}$ Som tidigare påpekat är unga oomtvistligt både receptiva och oskyddade i sina relationer till yttre betingelser. Med ett hypotetiskt exempel är det möjligt att åskådliggöra rimligheten i att alla barn inte tillskrivs samma receptiva känslighet. Vi kan exempelvis tänka oss barn till föräldrar med utländsk härkomst, som växer upp i invandrartäta bostadsområden. Genom sina skolprestationer säger vi att några av dessa barn uppvisar en sämre svenskbemästring. ${ }^{29}$ Det är då högst troligt att skolan i de flesta fall bedömer språksvårigheterna som miljörelaterade, det vill säga att de sociokulturella faktorerna i när- och boendemiljö försvårar språkinlärningen. Men om motsvarande språksvårigheter uppdagas hos barn med helsvenskt ursprung skulle dessa kunna påföras en språknormativ förväntan om likhet i språkutveckling, varför barnen och

25 Vad är socialt arbete? De flesta av oss som är verksamma inom sektorn vill nog gärna tro att vi kan svara på den frågan (även om det ter sig naivt utifrån alla olika professionsgrenar), men när är det vetenskapligt?

26 Huvuddelen av socialtjänstens myndighetsutövande medarbetare är kontorsbundna i sin praktiska yrkesutövning. Från en sådan position är insynen i människors levda praktik begränsad.

27 Socialt preventionsarbete förutsätter andra modeller och mål än somatiskt hälso- och preventionsarbete; det går inte att "vänja av" eller medicinera människor från att växa upp i socialt belastade bostadsområden och familjer så som vi vill vänja av människor från nikotin.

28 Bremberg S, Hjern A \& Widlund G (1996) Barns uppväxtmiljö styr kognitiv utveckling, Läkartidningen, 93, 161416. Analys av BVC's 4-åringstest som väl beskriver hur makrosociala mekanismer påverkar barns mentala utveckling. Idag är det särskilt kognitiva svårigheter hos barn och unga som ligger till grund för klinisk misstanke om neurobiologiska störningar.

29 Språk är förbundet med socialisering i ett specifikt samhälle eller grupp och dess kultur. Se bl. a Sjögren A et. al. (1996) En "bra" svenska? Om språk, kultur och makt. Mångkulturellt centrum. Reproprint AB, Sthlm. 
deras språkavvikelser kan bli föremål för psykologisk utredning. ${ }^{30}$ Med förmodan handlar det då om en förment uppfattning om ett jämlikt och språksammanhållet samhälle. Ett samhälle där inslag av sociokulturella olikheter inom en majoritetskultur, som bland annat effektueras i bristande språkutveckling eller sociolekter, inte ingår i de professionellas förförståelse. Att språkutveckling formas genom primära socialisationsprocesser, och inte genom skolan, är vetenskapligt belagt. Att språkbemästring är en god prognosfaktor för hälsa och social etablering är vetenskapligt belagt. Trots det finns det en risk att inblandade aktörer har svårt att navigera mellan de mest uppenbara grynnorna som i språkexemplet ovan. De yttre omständigheternas genomslagskraft blir med andra ord aldrig starkare än de professionellas kunskapsnivå. Därför kan olikheter idag vidhängas beskrivningar som yttringar av individuella val, andra menar att det är utslag av personliga egenskaper (temperament) eller medicinska svårigheter (nedsättning).

Sammantaget landar samhällets förståelse om olikheter i något som förmedlar att sociala betingelser inte spelar någon större roll alls. Sådana slutsatser förmodas vara vanligare i verksamheter som befolkas av yrkeskategorier som mycket sällan är eller aldrig varit i närheten av multisocialt nedbrytande miljöer (vare sig privat eller yrkesmässigt, ska väl tilläggas). Revisionistiska slutsatser dras förmodligen oftare av aktörer som inte heller har erforderlig skolning eller träning. ${ }^{31}$ Men dessa aktörer kan ändå ha en mycket tongivande roll när avvikelser, olikheter eller ohälsa definieras. Av den anledningen måste det finnas en danad kår som befinner sig i olikheternas landskap för att med nödvändighet ifrågasätta rådande kunskapsproduktion och initiera tvärvetenskapliga incitament om ohälsans orsakssamband. När ekologin är föränderlig och fragmentariserad krävs en klar blick över spelplanen, och den blicken måste höjas redan under kårens grundutbildning. En blick som ser en unik och viktig samhällsuppgift och som inte nöjer sig med att reduceras till perifera stödtrupper på individnivå. En viktig fråga i sammanhanget är om socialt arbete som samhällsvetenskaplig disciplin har tillräckligt med inomvetenskapliga resurser för att mejsla fram en profession som, åtminstone i dagsläget, både tangeras och överträffas av andra samhällsvetare $^{32}$ inom vissa ämnesområden?

30 Sen eller avvikande språkutveckling är en markör inom ADHD-kriterierna. Dålig språkutveckling anses också kunna leda till ADHD.

31 Det är bl.a. förunderligt hur det kommer sig att neurovetenskapens landvinningar om hur hjärnans utveckling påverkas av trauman och stress inte integreras vidare i förståelsen om problemskapande beteenden hos barn och unga. Vid sättande av ADHD-diagnos är det rimligt att patientens uppväxtvillkor underkastas analys om skadliga stressnivåer över lång tid.

32 Sociologi är det sociala arbetets ojämförbart största hjälpvetenskap med flertalet läroprofessurer inom ämnet, men hit måste även räknas psykologi, rättsvetenskap, pedagogik, genusvetenskap och statsvetenskap. 


\section{Socialpolitisk neutralitet}

Om mina hypoteser om en pågående biologisk revisionism inom välfärdssamhället av människors olycka och ohälsa stämmer, faller ett stort ansvar på politiker och andra beslutsfattare. ${ }^{33}$ De politiska institutionerna är ytterst ansvariga för synen på människa och samhälle. Politiken måste värdera vad som konstituerar människans tillvaro - vad är annars politiken till för? Aktuella rön ${ }^{34}$ visar att det förskrivs betydligt mer centralstimulerande medel i Sverige mot vad som tidigare har beräknats eller förväntats. Betyder det att människors problem har förenklats till att vara något som i huvudsak pendlar mellan hjärnans frontallob och DSM- $5^{35}$ och har de politiska lekmännen verkligen kompetens att identifiera vetenskapliga och kliniska anomalier? Merparten av de som hänvisas läkemedelsassisterad behandling är barn och unga. Och de unga har, som brukligt är, ett sämre skydd mot sentida fenomen (särskilt om föräldrar eller övrig familj är drabbade av multibristsamhällets ogynnsamma konsekvenser). När läkemedel träder in där den socialpolitiska debatten har klingat av, då har förmodligen samhället kontextuella, kulturella och mänskliga efterspel att vänta av icke överskådliga mått. Vem tar ansvar om 10-15 år för de psykosocialt underprivilegierade och utsatta grupper som fick sina förväntade reaktionsmönster omskrivna till neurobiologiska nedsättningar? Även den socialpolitiska debatten behöver en danad kår som vill ta plats i offentligheten. Inte minst för att det politiska landskapet förändrats drastiskt sedan 1960-1970-talen då det sociala arbetet implementerades som akademiskt ämne och samtidigt hade politiskt understöd genom socialdemokratins reformer med sikte på ekonomisk utjämning och fattigdomsfrågor. ${ }^{36}$ Det är en kår som behöver återerövra en unik och vetenskapsbaserad ${ }^{37}$ plats vid utformningen av samhälle och välfärd. Och det kommer förmodligen inte att ske förrän kåren kan enas om att de måste återerövra en övergiven identitet och profession.

Jan Valentin, fil mag i sociologi och verksam som chef inom socialpsykiatri

Kontakt: jan.valentin@kumla.se

33 Har de en klar blick över spelplanen, och om inte, vem är deras spanare och vilket kunskapsintresse företräder de?

34 http://www.lakemedelsverket.se/Alla-nyheter/Nyheter2013/Lakemedelsverket-foljer-upp-behandling-medcentralstimulantia-vid-ADHD/

35 Diagnostic and Statistical Manual of mental disorders. Diagnosmanual/psykiatrisk handbok som ges ut av American Psychiatric Association (APA).

36 Socialarbetarkårens samhörighet med politikens ambitioner medförde förmodligen att den också stod fri från andra professioners kunskapsintressen och -objekt.

37 Idag förefaller evidensbaserad praktik vara den forskningsanknytning som är prioriterad inom social sektor. Emellertid saknas data huruvida dessa praktiker har några relationer till erkända socialvetenskapliga teorier. 